\title{
Vestibular Schwannoma's Resection Surgical Approaches, Advantages and Disadvantages of Retrosigmoid, Middle Cranial Fossa and Translabyrinthine Surgical Approaches
}

\author{
Dr. Behzad Saberi* \\ Medical Research, Esfahan, Iran
}

Submission: July 26, 2020; Published: July 31, 2020

*Corresponding author: Dr. Behzad Saberi, Medical Research, Esfahan, Iran

\section{Mini Review}

There are various factors which would determine the selection of surgical approaches in resection of the vestibular schwannoma. Factors like experience of the surgeon, characteristics of the tumor, surgical anatomy and the patient's condition can determine the selection of the best surgical approach for individual cases with vestibular schwannoma. There are different opinions among surgeons about the pros and cons of selecting the surgical approaches for individual patients. This is a brief review on the advantages and disadvantages of three surgical approaches in resection of the vestibular schwannoma [1-4].

In Retrosigmoid approach, possibility of hearing preservation, posterior fossa's wide exposure, seventh cranial nerve's identification at the brain stem in the tumors with small sizes and the possibility to remove the whole tumor at once, are the advantages. Long recovery period, cerebellar retraction, postoperative headache which may appear early after surgery, limited access to lateral IAC because of the labyrinth's anatomical position and the necessity to remove the Intradural transmeatal bone in IAC accessing during surgery, are the disadvantages [5-9].

In Translabyrinthine approach, avoiding the retraction of the brain, IAC exposure entirely, accessing to the vestibular schwannoma tumor within the labyrinth, distal seventh cranial nerve's identification at the fundus and the possibility of combining this surgical approach with some other procedures like reconstructing the seventh cranial nerve, are the advantages of employing this surgical approach. Sigmoid sinus injury risk, long surgery time, impossibility to preserve the hearing ability and requirement for adipose graft from the abdomen, are the disadvantages of employing this surgical approach $[10,11]$.

In Middle cranial fossa approach, lateral IAC's early exposure, being primarily extradural approach and preserving

the hearing ability are the advantages. Requirement for retracting the temporal lobe, Inferior section of the fundus, brainstem, and CPA's limited exposure and seventh cranial nerve's position in relation to the vestibular schwannoma, are the disadvantages of employing the middle cranial fossa approach.

It is necessary for the surgeons to have enough knowledge about the surgical anatomy, advantages, and disadvantages of each surgical approach to reach the vestibular schwannoma tumors, to gain best surgical results with lowest surgical complications.

\section{References}

1. Isaacson B, Telian SA, El-Kashlan HK (2005) Facial nerve outcomes in middle cranial fossa vs translabyrinthine approaches. Otolaryngol Head Neck Surg 133(6): 906-910.

2. Slattery WH (2009) Microsurgery after radiosurgery or radiotherapy for vestibular schwannomas. Otolaryngol Clin North Am 42(4): 707715 .

3. Yamakami I, Ito S, Higuchi Y (2014) Retrosigmoid removal of small acoustic neuroma: curative tumor removal with preservation of function. J Neurosurg 121(3): 554-563.

4. Wang AC, Chinn SB, Than KD, Arts HA, Telian SA, et al. (2013) Thompson BG. Durability of hearing preservation after microsurgical treatment of vestibular schwannoma using the middle cranial fossa approach. J Neurosurg 119(1): 131-138.

5. Ansari SF, Terry C, Cohen-Gadol AA (2012) Surgery for vestibular schwannomas: a systematic review of complications by approach. Neurosurg Focus 33(3): E14.

6. Gardner G, Robertson JH (1988) Hearing Preservation in unilateral acoustic neuroma surgery. Ann Otol Rhinol Laryngol 97(1): 55-66.

7. Falcioni M, Fois P, Talbah A, Sanna M (2011) Facial nerve function after vestibular schwannoma surgery. J Neurosurg 115(4): 820-826.

8. Mamikoglu B, Wiet RJ, Esquivel CR (2002) Translabyrinthine approach for the management of large and giant vestibular schwannomas. Otol Neurotol 23(2): 224-227. 


\section{Cancer Therapy \& Oncology International Journal}

9. Schwartz MS, Kari E, Strickland M, Berliner K, Brackmann DE, et al (2013) Evaluation of the increased use of partial resection of large vestibular schwannomas: facial nerve outcomes and recurrence/ regrowth rates. Otol Neurotol 34(8): 1456-1464.

10. Ahmad RA, Sivalingam S, Topsakal V, Russo A, Taibah A, et al. (2012) Rate of recurrent vestibular schwannoma after total removal via different surgical approaches. Ann Otol Rhinol Laryngol 121(3): 158161.

11. Yates PD, Jackler RK, Satar B, Pitts LH, Oghalai JS (2003) Is it worthwhile to attempt hearing preservation in larger acoustic neuromas. Otol Neurotol 24(3): 460-464.

\section{Your next submission with Juniper Publishers} will reach you the below assets

- Quality Editorial service

- Swift Peer Review

- Reprints availability

- E-prints Service

- Manuscript Podcast for convenient understanding

- Global attainment for your research

- Manuscript accessibility in different formats ( Pdf, E-pub, Full Text, Audio)

- Unceasing customer service

Track the below URL for one-step submission https://juniperpublishers.com/online-submission.php 